\title{
GROWTH AND MINERAL COMPOSITION OF TROPICAL FORAGE LEGUMES INOCULATED WITH RHIZOBIA
}

\footnotetext{
Lucas Calazans Santos ${ }^{1}$, Marcela Tonini Venturini ${ }^{2}$, Caroline de Morais Pinheiro ${ }^{3}$, Eduardo Gross $^{3}$

${ }^{1}$ Instituto Capixaba de Pesquisa, Assistência Técnica e Extensão Rural - INCAPER - E-mail: lucas.santos@incaper.es.gov.br

${ }^{2}$ Universidade Federal do Recôncavo da Bahia - UFRB - E-mail: cosalin2@yahoo.com.br

${ }^{3}$ Universidade Estadual de Santa Cruz - UESC - E-mail: carolinefloresta@yahoo.com.br, egross@uesc.br
}

\section{ABSTRACT}

The objective of this paper was to evaluate the influence of indigenous and inoculated rhizobia and ammonium sulfate fertilizer on growth and mineral composition of the herbaceous legumes, Calopo (Calopogonium mucunoides), Ea Ea (Desmodium heterocarpon subsp. ovalifolium) and Kudzu (Pueraria phaseoloides), which are commonly used as forage plants and cover crops in Brazil. The treatments did not exhibit differences for total biomass of nodules. Lime application along with basic fertilization (without $\mathrm{N}$ ) permitted nodulation and full growth and development of forages with native rhizobia.

Keywords: Inoculation, legumes, nutrient, Rhizobium

\section{CRESCIMENTO E COMPOSIÇÃO MINERAL DE LEGUMINOSAS FORRAGEIRAS TROPICAIS INOCULADAS COM RIZÓBIOS}

\section{RESUMO}

O objetivo do presente estudo foi avaliar a influência de rizóbios nativos e inoculados, e o uso do fertilizante sulfato de amônio sobre o crescimento e a composição mineral de leguminosas herbáceas, calopogônio (Calopogonium mucunoides), desmódio (Desmodium heterocarpon subsp. ovalifolium) e puerária (Pueraria phaseoloides), que são utilizadas como forrageiras e plantas de cobertura no Brasil. Os teores de nutrientes foram adequados em todas as três espécies e não foram observadas diferenças. Rizóbios nativos foram tão eficazes quanto os rizóbios inoculados no fornecimento de $\mathrm{N}$ para as plantas. A biomassa total de nódulos não diferiu entre os tratamentos. A calagem, juntamente com adubação de base (sem N) permitiu a nodulação e crescimento integral e desenvolvimento de forrageiras com rizóbios nativos.

Palavras-chave: Inoculação, legumes, nutrientes, Rhizobium 


\section{INTRODUCTION}

Considerable interest in tropical countries, to evaluate the forage legumes yields grown in association with grasses especially in low fertility soils has increased in recent years (PERIN et al. 2004; VOLPE et al. 2008). Studies of association between legumes and grasses to become more importance mainly because of severe degradation of pasture lands, since close to 150 million hectares of pasture land in Brazil was degraded despite the availability of technology to prevent such degradation (CARVALHO \& PIRES, 2008).

Another advantage of herbaceous legumes is their use as a cover crop aiming to control weeds and soil erosion (ALTIERI, 1998). Herbaceous legumes are preferably used as green manure crops due to their low cost and this sustainable practice enable the improvement of chemical physical and biological properties of soil (GLIESSMAN, 2000).

Farmers have adapted forage legumes as cover crops or as green manure crops. Ea-Ea (Desmodium heterocarpon subsp. ovalifolium), Calopo (Calopogonium mucunoides) and Tropical Kudzu (Pueraria phaseoloides) are examples of legumes used as green manure and intercropped with grasses in Southern Bahia (FOSU et al.,
2004). These three legume species are commonly nodulated by rhizobia (nitrogen fixing bacteria).

The practice of legume inoculation with rhizobia is technically simple, efficient and is fully effective in improving $\mathrm{N}_{2}$ fixing process. LANZANOVA et al. (2010) pointed that the use of cover crops (legumes) was efficient in maintaining the soil physical conditions favorable to plant growth.

From the nutrient availability point of view this practice can reduce the cost of production by reducing $\mathrm{N}$ fertilizer input and further assist in conservation and improvement of soil (MOREIRA \& SIQUEIRA, 2006). This study aimed to evaluate the influence of indigenous and inoculated rhizobia in the early growth and nutrient content of Calopo, Ea-Ea and Kudzu, three herbaceous legumes.

\section{MATERIAL AND METHODS}

\section{Plants and growth conditions}

The experiment was conducted in a greenhouse, under natural light conditions, with three herbaceous perennial legumes, Desmodium heterocarpon (L.) DC. subsp. ovalifolium (Prain) H. Ohashi cv. Itabela (Ea Ea), Calopogonium mucunoides Desv. (Calopo) and Pueraria phaseoloides (Roxb.) 
Benth. (Kudzu) from October to December 2007.

All these species are naturally nodulated by rhizobia (sensu lato) and are similar with respect to their developmental pattern: sympodial erect herbs or shrubs. Calopo and Ea Ea are non-climbing while Kudzu is a climbing plant.

Seeds of Kudzu and Calopo were purchased from Piraí Sementes Company (Piracicaba, SP, Brazil) and Ea Ea seeds were kindly supplied by Dr. J. M. Pereira from CEPLAC (Comissão Executiva do Plano da Lavoura Cacaueira, Itabela, BA, Brazil). Seeds were surface sterilized by immersion in $90 \%$ ethanol (for $30 \mathrm{~s}$ ) followed by $1 \%$ sodium hypochlorite (for 3 min) and abundantly rinsed in distilled sterilized water. Seeds of Ea Ea and Kudzu were scarified with concentrate sulfuric acid for 3 minutes. About 10 seeds of all the three legumes were directly sown in the pots, which were daily watered with deionized water to maintain soil moisture at $70 \%$ of field capacity. Two weeks after germination, plants were thinned to reduce one plant per pot.

Arranged in a completely randomized design, the experiment was conducted in three treatments: (i) plants not inoculated with Rhizobium sp. (S); (ii) fertilized plants $(\mathrm{N})$ with $500 \mathrm{mg} \mathrm{dm}-3$ of ammonium sulfate and; (iii) plants inoculated (I) with Rhizobium sp. Each treatment contained 10 replicates except kudzu with 06.

Inoculation of Rhizobium sp. (isolate number 263 from UESC Rhizobia Bank) was performed with seeds in $10 \mathrm{ml}$ suspension of the YM (yeast mannitol) broth containing $10^{7} \mathrm{CFU}$ of bacteria. The fertilized ammonium sulfate was applied as solution directly on soil in pots.

All plants were grown in plastic pots (4.5 $\mathrm{dm}^{3}$ capacity) filled with $4 \mathrm{dm}^{3}$ of nonsterilized soil collected from Jassy Farm (15'15'13.3' ' S, 39'22'49.9', $\mathrm{W}$ and $99 \mathrm{~m}$ above sea level, Arataca municipality, Bahia State, Brazil). The soil was classified as a Typic Haplorthox (using US Soil taxonomy system) and composed by $59 \mathrm{~g} \mathrm{~kg}^{-1}$ of coarse sand, $70 \mathrm{~g} \mathrm{~kg}^{-1}$ of medium sand, $160 \mathrm{~g} \mathrm{~kg}^{-1}$ of fine sand, $127 \mathrm{~g} \mathrm{~kg}^{-1}$ of silt and $584 \mathrm{~g} \mathrm{~kg}^{-1}$ of clay. The chemical properties $(0-20 \mathrm{~cm})$ of this soil were: $\mathrm{pH} \quad\left(\mathrm{H}_{2} \mathrm{O}\right)$ 5.3, exchangeable cations (cmolc dm ${ }^{-3}$ ), $\mathrm{Ca}, 2.4$; $\mathrm{Mg}, 1.4$; K, 0.18; $\mathrm{Al}, 0.2$; available $\mathrm{P}$ (Mehlich), $0.8 \mathrm{mg} \mathrm{dm}{ }^{3}$; base saturation of $41 \%$; organic matter $23.87 \mathrm{mg} \mathrm{dm}^{-3}$.

A dolomitic lime $\left(3 \mathrm{t} \mathrm{ha}^{-1}\right)$ was applied to aim for $60 \%$ of base saturation followed by a basic fertilization with 79.8 
$\mathrm{mg} \mathrm{dm} .^{-3} \mathrm{~kg} \mathrm{~K} \mathrm{~K}_{2} \mathrm{O}$ (potassium chloride) and $400 \mathrm{mg} \mathrm{dm}^{-3} \mathrm{P}_{2} \mathrm{O}_{5}$ (supertriple phosphate) was applied to the soil. Micronutrients were applied on soil at the rates of: $1.55 \mathrm{mg} \mathrm{dm}^{-3}$ of iron, $0.75 \mathrm{mg} \mathrm{dm}^{-3}$ of boron, $1.33 \mathrm{mg} \mathrm{dm}^{-3}$ of cupper, $0.15 \mathrm{mg} \mathrm{dm}^{-3}$ of molybdenum, 4.0 $\mathrm{mg} \mathrm{dm}{ }^{-3}$ of zinc and $4.0 \mathrm{mg} \mathrm{dm}^{-3}$ of manganese. The resulting chemical properties of the soil after lime and fertilization applications (for each treatment) are presented (Table 1).

\section{Harvest}

After 8 weeks of growth, plants were harvested, and shoots and roots were separated. Roots were thoroughly washed to remove soil particles and nodules were counted. Dry weights of the shoots and nodules were recorded after drying for $72 \mathrm{~h}$ at $70^{\circ} \mathrm{C}$. Then shoot biomass was ground and digested to analyze macro and micronutrients (EMBRAPA 1997). Crude protein was calculated based on shoot dry matter. A composed sample of soil (30 g from each pot) from each treatment was analyzed for chemical properties (EMBRAPA, 1997) (Table 2).

\section{Statistical analyses}

A two-way analysis of variance (ANOVA) was used to test the effects of plant species (Calopo, Ea Ea and Kudzu) and $\mathrm{N}$ source treatment (ammonium sulfate fertilized, rhizobia inoculation and spontaneous nodulation) on each parameter measured. Comparisons (post hoc tests) between means of values from all combinations of species and treatments were carried out using the Tukey test at a significance level of $p \leq 0.05$. All statistical analyses were performed using Statistica 6.1 (StatSoft Inc., Tusla, OK, USA).

Table 1. Chemical properties of "Latossolo Vermelho-Amarelo" (Typic Haplorthox) soil from Jassy farm, localized in Arataca, Bahia State, Brazil after and before lime and fertilization, Ilhéus/Bahia, 2008.

\begin{tabular}{|c|c|c|c|c|c|c|c|c|c|c|c|c|c|c|c|c|c|c|}
\hline \multirow{3}{*}{ Sample } & \multirow{3}{*}{$\begin{array}{l}\mathrm{pH} \\
\mathrm{CaCl}_{2}\end{array}$} & \multirow{3}{*}{$\begin{array}{l}\mathrm{MO} \\
\mathrm{g} \mathrm{dm}\end{array}$} & \multirow[b]{2}{*}{$\mathrm{P}$} & \multirow[b]{2}{*}{ S } & \multirow[b]{2}{*}{$\mathrm{K}$} & \multirow[b]{2}{*}{$\mathrm{Ca}$} & \multicolumn{5}{|c|}{ Base } & \multirow{2}{*}{$\begin{array}{l}\text { Base } \\
\text { sat }\end{array}$} & \multicolumn{2}{|l|}{$\mathrm{Al}$} & \multirow[b]{2}{*}{$\mathrm{Cu}$} & \multirow[b]{2}{*}{$\mathrm{Fe}$} & \multirow[b]{2}{*}{ Mn } & \multirow{3}{*}{$\mathrm{Zn}$} \\
\hline & & & & & & & $\mathrm{Mg}$ & $\mathrm{Al}$ & $\mathrm{H}+\mathrm{Al}$ & sum & CEC & & sat & $\mathrm{B}$ & & & & \\
\hline & & & $\mathrm{mg}$ & $\mathrm{lm}^{-3}$ & ----. & ------ & ----- & $\mathrm{cmo}$ & $\mathrm{lc} \mathrm{dm}^{-3}$ & -- & ----- & $\%$ & & & & $\mathrm{~g} \mathrm{dm}$ & & \\
\hline $\begin{array}{l}\text { Fertilized } \\
\text { soil plus N }\end{array}$ & 5 & 37 & 260 & 127 & 0,6 & 5,5 & 2,2 & 0 & 3,8 & 8,3 & 12,1 & 69 & 0 & 0,27 & 1,7 & 93 & 5,6 & 3,7 \\
\hline Fertilized & & & & & & & & & & & & & & & & & & \\
\hline soil minus & 5,4 & 40 & 238 & 49 & 0,86 & 5,5 & 2,6 & 0 & 3,1 & 8,96 & 12,06 & 74 & 0 & 0,65 & 2,9 & 113 & 8,3 & 7 \\
\hline $\mathrm{N}^{* *}$ & & & & & & & & & & & & & & & & & & \\
\hline
\end{tabular}


Table 2. Chemical characteristics of soil before Calopo (C. mucunoides), Ea Ea (D. heterocarpon var. ovalifolium) and Kudzu (P. phaseoloides) plants harvest, Ilhéus/Bahia, 2008.

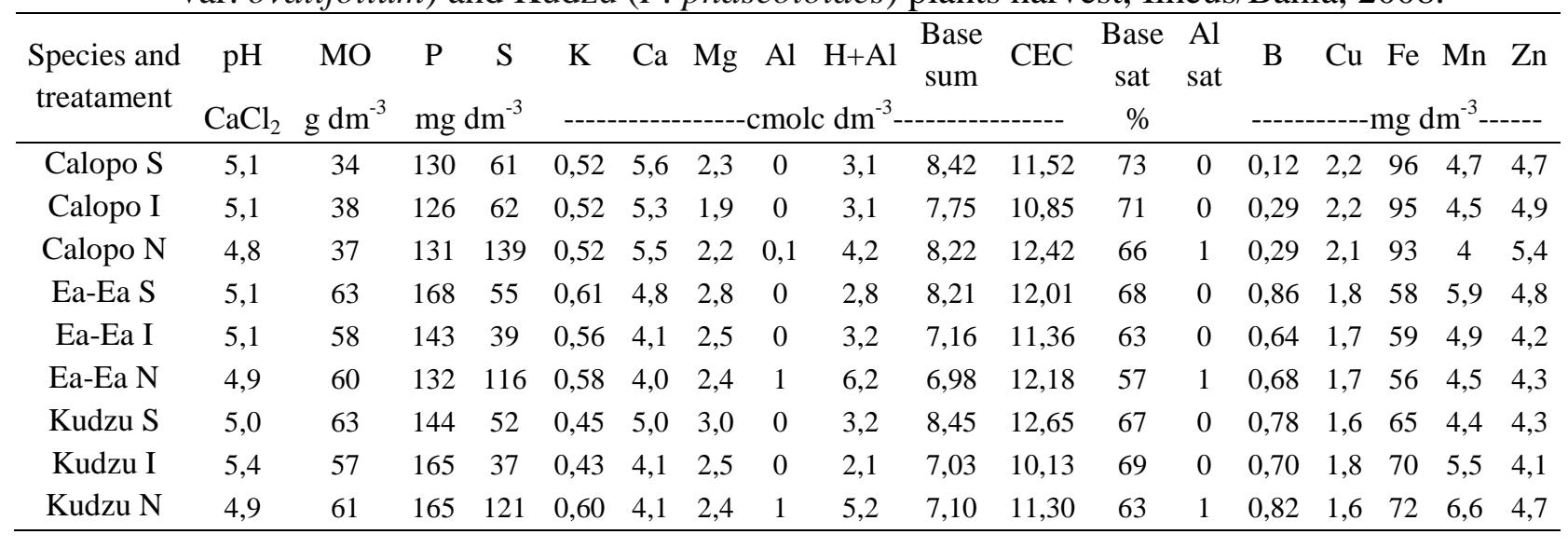

\section{RESULTS AND DISCUSSION}

Significant effects of species and interaction of species with $\mathrm{N}$ source demonstrated that shoot dry weight, nodule dry weight and shoot $\mathrm{N}$ content responded to applied N source (Table 3). Kudzu overall produced higher shoot dry mass, $\mathrm{N}$ content and nodule dry mass than the other two legumes in all the treatments (Figure 1 and 2).

The shoot dry weight was affected by $\mathrm{N}$ source in a species-specific manner (Figure 1). As with the shoot biomass, N content (Table 4) and nodule dry weight (Figure 2) also showed that Kudzu was more positively affected by rhizobia inoculation and by spontaneous nodulation than $\mathrm{Ea} \mathrm{Ea}$ and Calopo.
On the other hand ammonium sulfate fertilization caused a drastic reduction in shoot biomass, $\mathrm{N}$ content and nodule dry weight in Kudzu and just a slight reduction was observed in Ea Ea and Calopo.

The shoot crude protein in all legume species decreased in ammonium sulfate treated plants (Figure 3). Kudzu and Calopo showed crude protein content higher than in Ea Ea tissue. $\mathrm{N}$ concentration in shoot tissue (Table 4) and even shoot $\mathrm{N}$ content decreased with ammonium sulfate fertilization independently of legume species. Other macronutrients concentration (P, K, Ca, Mg and S) among three legumes were not different (Table 4). The treatments had no influence on the concentrations of macronutrients in shoot. 
Table 3. Results of the two-way analysis of variance for parameters in the $\mathrm{N}$ source experiment with Calopo, Ea Ea and Kudzu, Ilhéus/Bahia, 2008.

\begin{tabular}{|c|c|c|c|c|c|c|c|c|c|}
\hline \multirow[t]{2}{*}{ Parameter } & \multicolumn{3}{|c|}{ Species } & \multicolumn{3}{|c|}{$\mathrm{N}$ source } & \multicolumn{3}{|c|}{$\begin{array}{c}\text { Species } \times \mathrm{N} \text { source } \\
\text { interaction }\end{array}$} \\
\hline & $d f$ & $\mathrm{~F}$ & $P$ & $D f$ & $\mathrm{~F}$ & $P$ & $d f$ & $\mathrm{~F}$ & $P$ \\
\hline Shoot dry weight & 2 & 103,7 & 0,000 & 2 & 22,3 & 0,000 & 4 & 24,2 & 0,000 \\
\hline Nodule dry weight & 2 & 112,3 & 0,000 & 2 & 50,1 & 0,000 & 4 & 10,4 & 0,000 \\
\hline Shoot $\mathrm{N}$ content & 2 & 113,5 & 0,000 & 2 & 61,9 & 0,000 & 4 & 32,4 & 0,000 \\
\hline Shoot $\mathrm{N}$ concentration & 2 & 97,71 & 0,000 & 2 & 15,90 & 0,000 & 4 & 1,21 & 0,317 \\
\hline Shoot $\mathrm{P}$ concentration & 2 & 22,5 & 0,000 & 2 & 0,81 & 0,447 & 4 & 1,82 & 0,135 \\
\hline Shoot $\mathrm{K}$ concentration & 2 & 29,53 & 0,000 & 2 & 4,96 & 0,010 & 4 & 2,22 & 0,076 \\
\hline
\end{tabular}

Factors were: species (Calopo, Ea Ea and Kudzu) and $\mathrm{N}$ source (Ammonium sulfate fertilized plants, rhizobia inoculated plants and spontaneously nodulated plants).

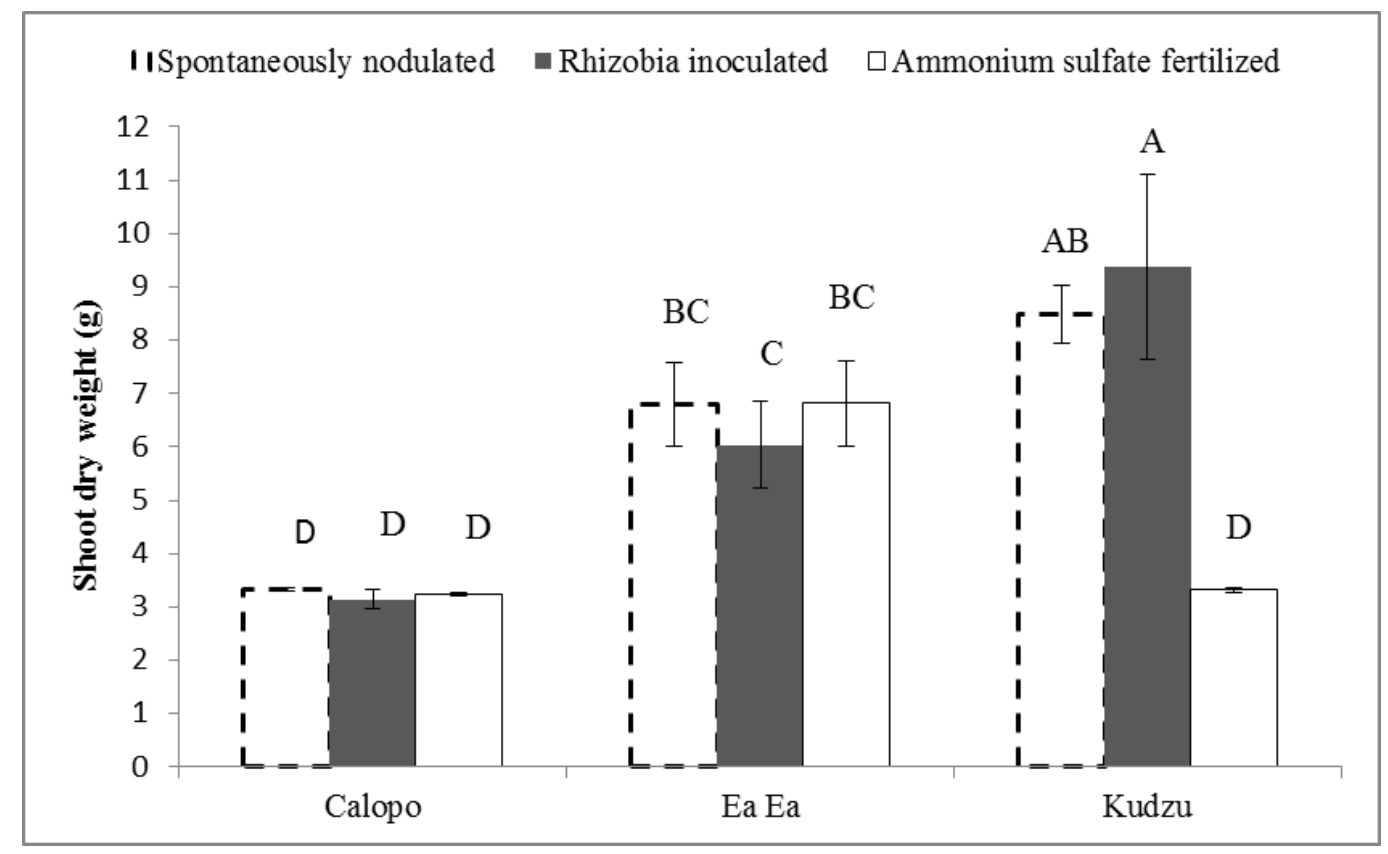

Figure 1. Effect of indigenous soil rhizobia, fertilization and rhizobia inoculation on shoot dry weight of Calopo, Ea Ea and Kudzu plants. Values are means \pm SE ( $n=10$ except for Kudzu that $\mathrm{n}=6$ ) and bars marked with the same letter did not differ significantly at $p \leq .0 .05$, Ilhéus/Bahia, 2008. 


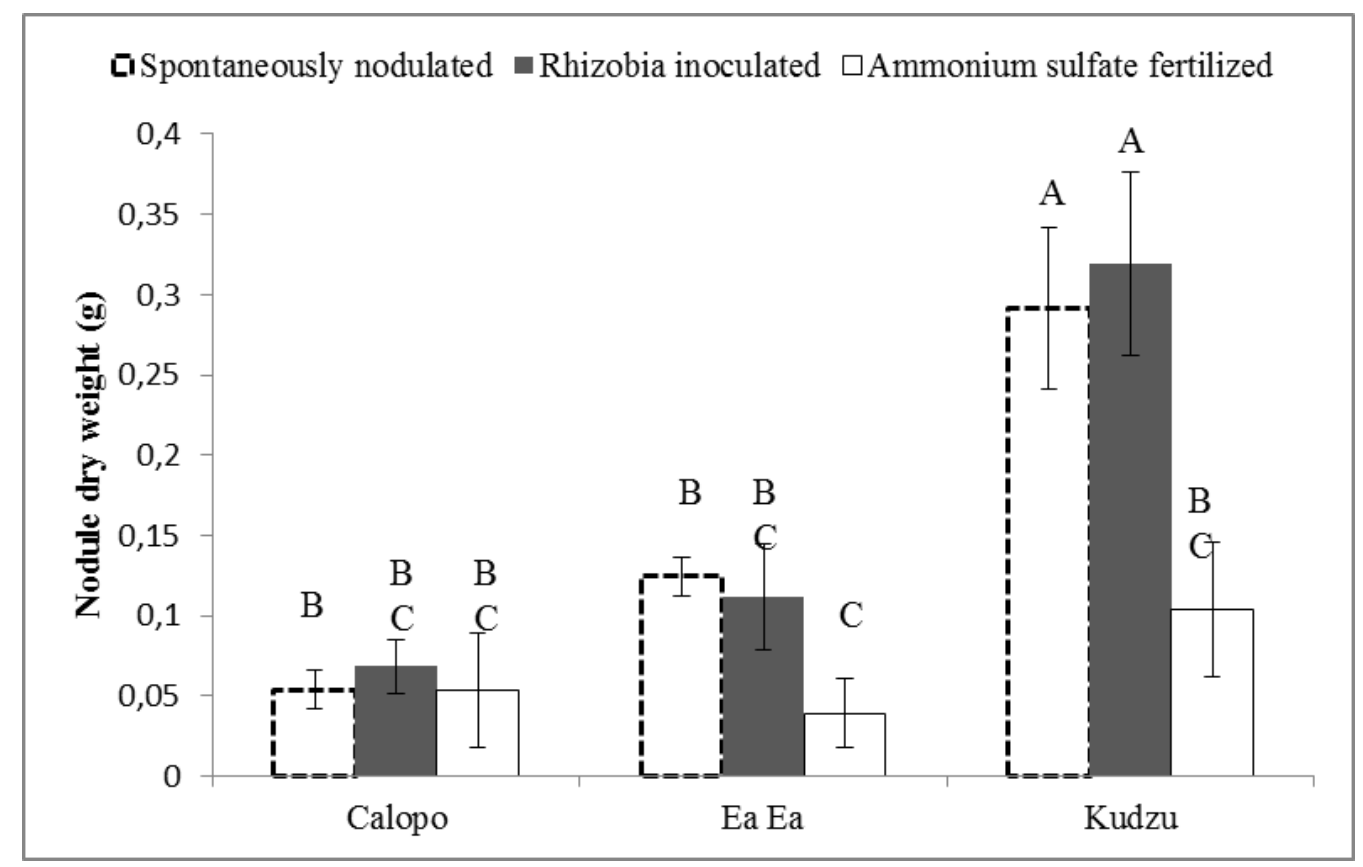

Figure 2. Effect of indigenous soil rhizobia, fertilization and rhizobia inoculation on nodule dry weight of Calopo, Ea Ea and Kudzu plants. Values are means \pm SE $(n=6)$ and bars marked with the same letter did not differ significantly at $p \leq .0 .05$, Ilhéus/BA, 2008.

Table 4. Means content of macro and micronutrients of shoot in Calopo (Calopogonium mucunoides), Ea Ea (Desmodium heterocarpon var. ovalifolium) and Kudzu (Pueraria phaseoloides) plants submitted to indigenous soil rhizobia (S), rhizobia inoculation (I) and fertilization with mineral nitrogen (N), Ilhéus/Bahia, 2008.

\begin{tabular}{|c|c|c|c|c|c|c|c|c|c|c|c|}
\hline \multirow{2}{*}{$\begin{array}{l}\text { Species } \\
\text { and } \\
\text { treatament }\end{array}$} & $\mathrm{N}$ & $\mathrm{P}$ & $\mathrm{K}$ & $\mathrm{Ca}$ & $\mathrm{Mg}$ & $S$ & B & $\mathrm{Cu}$ & $\mathrm{Fe}$ & $\mathrm{Mn}$ & $\mathrm{Zn}$ \\
\hline & \multicolumn{6}{|c|}{$\mathrm{g} \mathrm{kg}^{-1}$} & \multicolumn{5}{|c|}{$\mathrm{mg} \mathrm{kg}^{-1}$} \\
\hline Calopo S & $32,55^{\mathrm{a}}$ & $2,86^{\mathrm{a}}$ & $25,68^{\mathrm{a}}$ & $8,86^{\mathrm{a}}$ & $1,59^{\mathrm{a}}$ & $1,74^{\mathrm{a}}$ & $80^{\mathrm{a}}$ & $7,38^{\mathrm{a}}$ & $603,22^{\mathrm{a}}$ & $3,69^{\mathrm{b}}$ & $29,03^{\mathrm{a}}$ \\
\hline Calopo I & $33,97^{\mathrm{a}}$ & $2,92^{\mathrm{a}}$ & $27,05^{\mathrm{a}}$ & $9,31^{\mathrm{a}}$ & $1,67^{\mathrm{a}}$ & $1,60^{\mathrm{a}}$ & $61,78^{a}$ & $6,51^{a}$ & $5,50^{\mathrm{a}}$ & $29,04^{\mathrm{b}}$ & $32,49^{\mathrm{a}}$ \\
\hline Calopo N & $29,58^{\mathrm{ab}}$ & $2,99^{\mathrm{a}}$ & $23,74^{\mathrm{a}}$ & $10,46^{\mathrm{a}}$ & $2,30^{\mathrm{a}}$ & $1,84^{\mathrm{a}}$ & $67,91^{\mathrm{a}}$ & $5,21^{\mathrm{a}}$ & $1063,50^{\mathrm{a}}$ & $58,92^{\mathrm{a}}$ & $31,62^{\mathrm{a}}$ \\
\hline Ea-Ea S & $25,09^{\mathrm{b}}$ & $2,53^{\mathrm{a}}$ & $18,64^{\mathrm{a}}$ & $10,20^{\mathrm{a}}$ & $2,10^{\mathrm{a}}$ & $1,71^{\mathrm{a}}$ & $54,50^{\mathrm{a}}$ & $7,94^{\mathrm{a}}$ & $219,46^{\mathrm{a}}$ & $38,65^{\mathrm{b}}$ & $28,67^{\mathrm{a}}$ \\
\hline Ea-Ea I & $22,44^{\mathrm{bc}}$ & $2,60^{\mathrm{a}}$ & $19,20^{\mathrm{a}}$ & $9,94^{\mathrm{a}}$ & $1,96^{\mathrm{a}}$ & $1,69^{\mathrm{a}}$ & $57,00^{\mathrm{a}}$ & $7,56^{\mathrm{a}}$ & $199,21^{\mathrm{a}}$ & $31,81^{\mathrm{b}}$ & $28,67^{\mathrm{a}}$ \\
\hline Ea-Ea N & $18,84^{\mathrm{c}}$ & $2,27^{\mathrm{a}}$ & $19,10^{\mathrm{a}}$ & $10,43^{\mathrm{a}}$ & $2,64^{\mathrm{a}}$ & $1,79^{\mathrm{a}}$ & $58,22^{\mathrm{a}}$ & $6,01^{\mathrm{a}}$ & $299,21^{\mathrm{a}}$ & $64,08^{\mathrm{a}}$ & $27,22^{\mathrm{a}}$ \\
\hline Kudzu S & $35,23^{\mathrm{a}}$ & $2,88^{\mathrm{a}}$ & $20,10^{\mathrm{a}}$ & $8,61^{\mathrm{a}}$ & $2,70^{\mathrm{a}}$ & $1,63^{\mathrm{a}}$ & $62,65^{\mathrm{a}}$ & $10,31^{\mathrm{ab}}$ & $458,33^{\mathrm{a}}$ & $53,61^{\mathrm{b}}$ & $39,68^{\mathrm{a}}$ \\
\hline & 33,8 & $2,79^{\mathrm{a}}$ & $26,18^{\mathrm{a}}$ & $7,68^{\mathrm{a}}$ & $2,28^{\mathrm{a}}$ & $1,62^{\mathrm{a}}$ & $61,94^{\mathrm{a}}$ & $10,97^{\mathrm{b}}$ & $651,67^{\mathrm{a}}$ & $68,83^{\mathrm{b}}$ & $33,42^{\mathrm{a}}$ \\
\hline Kudzu N & $30,10^{\mathrm{ab}}$ & $2,78^{\mathrm{a}}$ & $22,82^{\mathrm{a}}$ & $8,51^{\mathrm{a}}$ & $2,63^{\mathrm{a}}$ & $1,45^{\mathrm{a}}$ & $62,17^{\mathrm{a}}$ & $7,47^{\mathrm{a}}$ & $730,00^{\mathrm{a}}$ & $146,23^{\mathrm{a}}$ & $35,92^{\mathrm{a}}$ \\
\hline
\end{tabular}

Within each column, means followed by the same letter are not statistically significant at $p \leq 0.05$. 


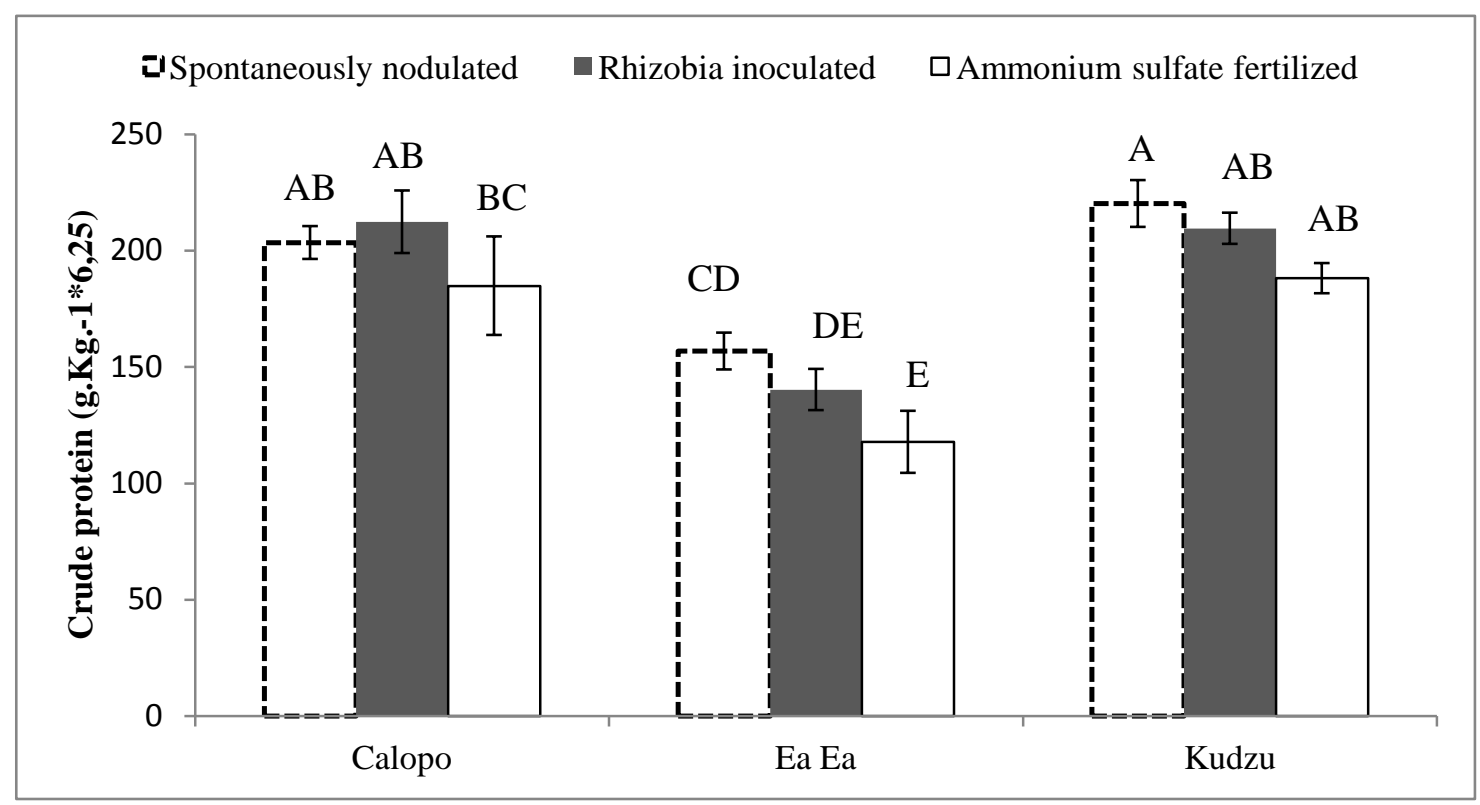

Figure 3. Effect of indigenous soil rhizobia, fertilization and rhizobia inoculation on shoot crude protein in Calopo, Ea Ea and Kudzu plants. Values are means \pm SE ( $n=10$ except for Kudzu that $\mathrm{n}=6$ ) and bars marked with the same letter did not differ significantly at $p \leq .0 .05$, Ilhéus/Bahia, 2008.

However

micronutrient

concentrations were influenced by different treatments (Table 4) and with exception of Mn concentration of micronutrients in forage species shoot were higher with ammonium fertilizer than the other two treatments.

Although in the current study there was no correlation was observed between the number of nodules and shoot dry mass (SDM), several studies have linked the number of nodules in nitrogen fixation and plant biomass (MOREIRA \& SIQUEIRA, 2006).

It is known that application of high levels of nitrogen fertilizer inhibit nodulation (WATERER \& VESSEY, 1993). Patriarca et al. (2002) reported that fertilization with $\mathrm{NH}_{4}{ }^{+}$form of $\mathrm{N}$ can turn negative signals from the root cortical cell division by inhibiting the initial training in the legume nodule. Furthermore, the $\mathrm{NH}_{4}{ }^{+}$inhibits the deformation of the root, which is required for entry of rhizobia in the root and the apical meristem of inactive nodules already formed. Patriarca et al. (2002) they also state that $\mathrm{NH}_{4}{ }^{+}$produced within the node may have a positive effect on the nodulation, but when this ion is absorbed directly from the soil by legumes it gives a negative effect by inhibiting the formation of nodules. This seemed to occur in treatments with nitrogen fertilizer (ammonium sulfate) of Ea Ea and 
kudzu which showed lower numbers of nodules. Such reduction in nodule number is reflected in lower dry weight of nodules.

SHOCKLEY et al. (2004) reported that average nodulation in Desmodium paniculatum, were lower than in Desmodium heterocapon subsp. ovalifolium (Prain). High rates of nitrogen and organic matter content could influence the degree of nodulation. This may be a factor between these two species in question (MOREIRA \& SIQUEIRA, 2006).

The low amount of shoot dry mass in kudzu plants fertilized with nitrogen (Figure 1), can be explained by the fact that some species of legumes, according to MELLONI et al. (2006), do not tolerate higher levels of N. Application of high $\mathrm{N}\left(100 \mathrm{mg} \mathrm{dm}^{-3}\right.$ of $\left.\mathrm{N}\right)$ together high organic matter $\left(61 \mathrm{~g} \mathrm{dm}^{-3}\right)$ content of soil may be the cause of low SDM in Kudzu in this study.

ESPINDOLA et al. (2006) reported that kudzu had higher dry mass production than Arachis pintoi and Macroptilium atropurpureum (siratro) without mineral nitrogen fertilization application. BODDEY et al. (2004) observed that the key to decline in pasture growth, among other factors, is related to the loss of $\mathrm{N}$ and consequent reduction of other nutrients responsible for plant development. The absence of symptoms of deficiency along with analysis of leaf tissue of Ea Ea, Kudzu and Calopo indicated that both native (because the soil was not sterilized) and inoculated rhizobia supply the $\mathrm{N}$ to the plants. This shows the efficiency of native and inoculated rhizobia to fix $\mathrm{N}_{2}$.

PERIN et al. (2004) reported that kudzu showed higher dry mass production and increased accumulation of $\mathrm{N}$ and $\mathrm{K}$ at a density of 10 plants $\mathrm{m}^{-2}$ and a spacing of 25 $\mathrm{cm}$ between rows. Evaluations, 5 months after planting resulted an average of $25,97 \mathrm{~g}$ $\mathrm{kg}^{-1}$ of $\mathrm{N}$ and $9,16 \mathrm{~g} \mathrm{~kg}^{-1}$ of $\mathrm{K}$. Results of the present experiment showed values of $\mathrm{N}$ and $\mathrm{K}$ for kudzu higher than those found by (PERIN et al. 2004), who performed evaluation after 2 months of growing in pots and different rates of fertilizers and nutrients were used. These results reinforce the assertion that this legume properly fertilized could posses appropriate levels of nutrients in its own biomass like a potential source for ruminant nutrition.

Liming at the beginning of the experiment may have aided in the higher absorption of $\mathrm{N}$ by $\mathrm{Ea} \mathrm{Ea}$, Calopo and Kudzu plants and improving the symbiotic fixation of $\mathrm{N}_{2}$ due to the formation of larger number of nodules. CAIRES \& ROSOLEM (2000) and VOLPE et al. (2008), reported 
the influence of liming in increasing the uptake of nitrogen by the legume.

OLIVEIRA et al. (2004) reported that one of the simplest and most reliable indicators for degraded pastures is the capacity of regrowth after cutting, among other factors directly related to current soil fertility and soil fertilization. So liming becomes a necessary practice to increase the regrowth capacity of forage plants.

\section{CONCLUSION}

The inoculated and native soil rhizobia were effective in biological $\mathrm{N}$ fixation and application of ammonia fertilizer to legumes is as effective as rhizobium application alone. The mineral nitrogen fertilization tended to reduce the nitrogen content, as well as the percentage of crude protein in shoot, especially in Ea Ea. Among the studied species kudzu presented the lowest shoot dry mass production with mineral nitrogen fertilization, indicating incompatibility between biomass production and in relation to biomass production and mineral fertilization.

\section{ACKNOWLEDGEMENTS}

We thank Dr. Virupax Baligar for his excellent technical review and the FABESB for support the scholarship.

\section{REFERENCES}

ALTIERI, M. 1998. Agroecologia: a dinâmica produtiva da agricultura sustentável. UFRGS, Porto Alegre, Brasil, 120p.

BODDEY, R.M.; MACEDO, R.; TARRÉ, R; FERREIRA, E.; OLIVEIRA, O.C.; RESENDE, C.P.; CANTARUTTI, R.B.; PEREIRA, J.M.; ALVES, B.J.R.; URQUIAGA S. 2004. Nitrogen cycling in Brachiaria pastures: the key to understanding the process of pasture decline. Agriculture, Ecosystem and Environment, Amsterdam, v.103, p 389-403.

CAIRES, E.F.; ROSOLEM, C.A. 2000. Nodulation and nitrogen uptake by peanut as affected by lime, cobalt, and molybdenum. Scientia Agricola, Piracicaba, v. 57, p. 337-341.

CARVALHO, G.G.P.; PIRES, A.J.V. 2008. Leguminosas tropicais herbáceas em associação com pastagens. Archivos de Zootecnia, Viçosa, v. 57, p. 103-113.

EMBRAPA. 1997. Centro Nacional de Pesquisa de Solos. Manual de métodos de análise de solos. ed. rev. Atual, Rio de Janeiro, Brasil, 212p.

ESPINDOLA J.A.A.; GUERRA J.G.M.; PERIN A.; TEIXEIRA M.G.; ALMEIDA D.L.; URQUIAGA S.; BUSQUET R.N.B. 2006. Bananeiras consorciadas com leguminosas herbáceas perenes utilizadas como coberturas vivas. Pesquisa agropecuária brasileira, Brasília, v.41, p. 415-420.

FOSU M.; KÜHNE R.F.; VLEK, P.L.G. 2004. Improving maize yield in the Guinea Savanna zone of Ghana with leguminous cover crops and PK. Journal of Agronomy, Winnipeg, v.3, p. $115-121$.

GLIESSMAN S.R. 2000. Agroecologia: processos ecológicos em agricultura 
sustentável. UFRGS, Porto Alegre, Brasil, 637p.

LANZANOVA, M.E.; ELTZ, F.L.F.; NICOLOSO, R.S.; AMADO, T.J.C.; REINERT, D.J.; ROCHA, M.R. 2010. Atributos físicos de um argissolo em sistemas de culturas de longa duração sob semeadura direta. Revista Brasileira de Ciência do Solo, Viçosa, v. 34, p. 1333-1342.

MELLONI, R.; MOREIRA, F.M.S.; NOBREGA, R.S.A.; SIQUEIRA, J.O. 2006. Eficiência e diversidade fenotípica de bactérias diazotróficas que nodulam caupi (Vigna unguiculata (L.) Walp) e feijoeiro (Phaseolus vulgaris L.) em solos de mineração de bauxita em reabilitação. Revista Brasileira de Ciência do Solo, Viçosa, v.30, p. 235246.

MOREIRA, F.M.S.; SIQUEIRA, J.O. 2006. Microbiologia e bioquímica do solo. UFLA, Lavras, Brasil, 729p.

OLIVEIRA, O.C.; OLIVEIRA, I.P.; URQUIAGA， S.; ALVES, B.J.R; BODDEY, R.M. 2004. Chemical and biological indicators of decline/degradation of Brachiaria pastures in the Brazilian cerrado. Agriculture, Ecosystems and Environment, Amsterdam, v.103, p. 289-300.

PATRIARCA, E.J.; TATE, R.; IACCARINO, M. 2002. Key Role of Bacterial $\mathrm{NH}_{4}{ }^{+}$Metabolism in Rhizobium-Plant Symbiosis. Microbiology and Molecular Biology Reviews, Washington, v.66, p. 203-222. PERIN, A.; GUERRA, J.G.M.; TEIXEIRA, M.G.; ZONTA E. 2004. Cobertura do solo e estoque de nutrientes de duas leguminosas perenes, considerando espaçamentos e densidades de plantio. Revista Brasileira de Ciências do Solo, Viçosa, v.28, p.207-213.

SHOCKLEY, F.W.; MCGRAW, R.L.; GARRETT, H.E. 2004. Growth and nutrient concentration of two native forage legumes inoculated with Rhizobium and Mycorrhiza in Missouri, USA. Agroforestry Systems, Dordrecht, v. 60, p.137-142.

VOLPE, E.; MARCHETTI, M.E.; MACEDO, M.C.M.; ROSA JUNIOR, E.J. 2008. Renovação de pastagem degradada com calagem, adubação e leguminosa consorciada em Neossolo Quartzarênico. Acta Scientiarum Agronomy, Maringá, v.30, p. 131-138.

WATERER, J.G.; VESSEY, J.K. 1993. Effect of low static nitrate concentrations on mineral nitrogen uptake, nodulation, and nitrogen fixation in field pea. Journal of Plant Nutrition, Winnipeg, v.16, p. 17751789. 